\title{
MALREV
}

\section{STRENGTHENING RISK MANAGEMENT OF SHARIA BANKING IN INDONESIA}

\author{
Miftah Idris \\ Faculty of Law in Muhammadiyah University of Luwu Banggai \\ Email: miftah.idris@mail.ugm.ac.id
}

\begin{abstract}
The risk faced by sharia banking in channeling funds through financing is the biggest source of risk for business operations, because the presence of problematic financing not only lowers income for Islamic banks but also affects the health of Islamic banks. Therefore, risk management is needed to identify, measure, monitor and control risks in accordance with Islamic banking business activities. The purpose of this study is how efforts are made to improve the optimization of risk management in Islamic Banking. The research method used is descriptive legal research or literature with a type of qualitative research. The results of the study found that there is a need for optimization of institutions and systems in strengthening risk management in Islamic banking today.
\end{abstract}

Keywords: Strengthening, Risk Management, Islamic Banking.

Abstrak: Risiko yang dihadapi oleh perbankan syariah dalam menyalurkan dana melalui pembiayaan adalah sumber risiko terbesar untuk operasional bisnis, karena kehadiran pembiayaan bermasalah tidak hanya menurunkan pendapatan bagi bank syariah tetapi juga mempengaruhi kesehatan bank syariah. Oleh karena itu, manajemen risiko diperlukan untuk mengidentifikasi, mengukur, memantau dan mengendalikan risiko sesuai dengan kegiatan bisnis perbankan syariah. Tujuan dari penelitian ini adalah bagaimana upaya dilakukan untuk meningkatkan optimalisasi manajemen risiko di Perbankan Syariah. Metode penelitian yang digunakan adalah penelitian hukum deskriptif atau literatur dengan jenis penelitian kualitatif. Hasil penelitian menemukan bahwa ada kebutuhan untuk optimalisasi lembaga dan sistem dalam memperkuat manajemen risiko di perbankan syariah saat ini.

Kata Kunci: Penguatan, menajemen resiko, Perbankan syariah

\section{BACKGROUND}

The increasing public demand for sharia-based banking cannot be denied at this time, because it is considered as an alternative banking system that has been a solution for the people of Indonesia. However, that does not mean there are no risks to be faced in it.

Sharia banking business activities are the same as dealing with banking which is another that is known as conventional banking, which requires risk management. This risk management is regulated so that it can, at the very least, minimize the risks that have already been predicted to occur. Not only that, the complexity of the risks involved in Islamic banking is greater, such as the involvement of customers and the wider community as well as the broader conditions of economic stability. 


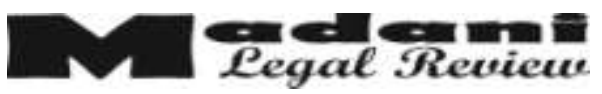

The risk and implementation of risk management in Islamic banking is more complicated. Considered to be more complicated, at least due to two things, firstly Islamic banks face financing, market, liquidity and operational risk risks. Second, the risks mentioned above will face different conditions when dealing with the obligation to comply with sharia principles, in addition to the asset structure and liabilities of Islamic banking. They must also be able to design their own systems in accordance with the character of the activists they run. ${ }^{1}$ Based on the background, the formulations of the problem to be raised are What is the management concept in the Islamic economy that we know and What should be done to optimize the risk management of Islamic banking.

\section{RESEARCH METHOD}

\section{a. Type of Research}

The type of research used is Descriptive Research, which provides an overview of the risk management of Islamic banking, so that an explanation of the discussion will be obtained.

\footnotetext{
Tariqullah Khan dan Habib Ahmed, Risk Management, An Analysis of Issues in Islamic Financial Industry, Occasional Paper, IDB and IRTI, Jeddah, 2000, p. 21, see also on Hennie Van Greuning and Zamir Iqbal, 2008, Risk Analysis for Islamic Banks, World Bank, Washington DC.
}

\section{b. Type of Data}

The type of data used is a secondary data type where the data generated from this study is library data or secondary data. To obtain this secondary data the authors conducted a search of primary, secondary and tertiary legal materials.

\section{c. Troubleshooting Techniques}

After getting the data related to this research, the data will be analyzed in several ways to get the results of qualitative research later. The commonly used way is to classify the data then the systematized data and then interpret it critically. After the process has been passed, the last of the data will be reevaluated to support the resolution of a problem in the study. ${ }^{2}$

\section{DISCUSSION}

\section{Definition}

In general, risks can be defined in various ways, for example as an adverse event or risk is for investment analysis and risk is a deviation of the results obtained from the expected. However, there are two aspects in terms of risks that are considered, namely probabilities / possibilities and aspects of loss / impact. ${ }^{3}$

\footnotetext{
Soejono Soekanto, Pengenalan Penelitian Hukum, (Jakarta:Grafindo, 2006) p. 225

3 Veithzal Rivai and Rifki Ismail, Islamic Risk Management for Islamic Banking, (Jakarta: Gramedia, 2013) p. 56
} 


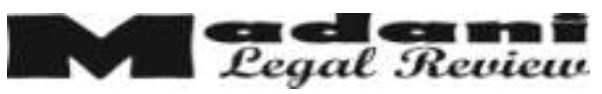

Risks and uncertainties are two different things in their use. Risk refers to expected risk, while uncertainty refers to the definition of unexpected risk.

Eddie $\mathrm{Cade}^{4}$ argues that the definition of risk varies, depending on its purpose. According to him, if viewed from the bank's perspective, it is an exposure to income uncertainty. Another opinion expressed by Philip Best ${ }^{5}$ stated that risk is financial loss, both directly and indirectly. Bank risk is openness to possible losses (exposure to the change of loss). According to Bank Indonesia Regulation (PBI), the bank's business risk is the risk associated with managing a bank's business as a financial intermediary. ${ }^{6}$

Djojosoedarsono noted several general notions of risk as stated by several authors, including ${ }^{7}$ :

a. Risk is a variation of results that can occur over a period of time (Arthur Williams and Richard MH.).

b. The risk is uncertainty that might give birth to a loss event (A. Abas Salim).

Eddie Cade, Managing Banking Risk, American Management Association, New York, 1999 ) p. 79.

Philip Best, Implementing Value at Risk, John Wiley \& Sons Ltd., West Sussex, 1998) p. 30 Veithzal Rivai and Rifki Ismail, Op.Cit., p. 57. Soeisno Djojosoedarsono, Prinsip-Prinsip Manajemen Risiko dan Asuransi, (Jakarta: Salemba Empat, 1999) p.1-2 c. Risk is uncertainty over the occurrence of events (Soekarto).

d. Risk is the spread / deviation of actual results from the expected results (Herman Darmawi).

e. Risk is the probability of a result that is different from what is expected (Herman Darmawi).

In the context of finance and economics, as stated by Heffernan, ${ }^{8}$ risk is defined as volatility or standard deviation from the net cash flow of a company / business unit. Risk exists when there is a possibility that the outcome of an event is not only one and the greatest outcome is unknown. Risk is also changes or movements of unexpected outcomes. ${ }^{9}$ The possibility of the bank experiencing losses as a result of changes in conditions that affect the value of the bank's position, including among the definition of risk. ${ }^{10}$

Based on the definition of risk above, risk management in general is the implementation of management functions in risk management. ${ }^{11}$ Practically,

Santoso, Wimboh and Enrico Heriantoro, "Market Risk di Perbankan Indonesia", Kajian Stabilitas Keuangan, No. 1 June, Jakarta, Bank Indonesia, 2003. p.76

9 Tariqullah Khan and Habib Ahmed, Risk Management; An Analysis of Issues In Islamic Financial Industry, Occasional paper, IDB and IRTI, Jeddah, 2001) p. 21

10 Santoso, Wimboh and Enrico Heriantoro, Ibid

11 Soesisno Djojosoedarsono, Prinsip-Prinsip Manajemen Risiko dan Asuransi, (Jakarta: Salemba Empat, 1999) p. 4 


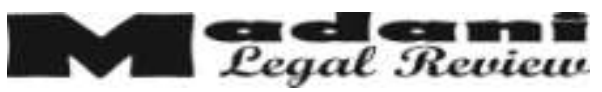

Tampubolon provides an understanding of risk management, as follows: ${ }^{12}$

a. Bank Indonesia defines risk management as "a series of procedures and methodologies used to identify, measure, monitor, and control risks arising from bank business activities" (PBI No. 5/8 / PBI / 2003).

b. Widigdo Sukarman defines risk management as: "the overall system of risk management and control faced by banks that consists of a set of tools, techniques, management processes (including authority and systems and operational procedures) and organizations aimed at maintaining the level of profitability and soundness of the bank has been determined in a corporate plan or other bank's strategic plan in accordance with the prevailing bank soundness level."

c. William T. Tornhill provides a definition of risk management by: "as a management discipline whose purpose is to protect the assets and profits of an organization by reducing potential

Roberst Tampubolon, Risk Management, Qualitative Approach Aplied to Commercial Bank, (Jakarta: PT. Elex Media Komputindo, 2004) p.33-34 losses before they occur, and financing through insurance or other means for possible large losses due to natural disasters, negligence humans, or because of court decisions. In practice, this process includes logical steps such as identifying risks, measuring and assessing exposures that have been identified, controlling those threats through elimination or reduction; and financing the remaining threats so that if losses continue to occur, the organization can continue to run its business without being disturbed by its financial stability."

In other sources, risk management can also be defined as a series of procedures and methodologies used to identify, measure, monitor, and control risks arising from the bank's business activities. This is related to the general definition of risk, that is, in every business or activity there is always the possibility of not achieving a goal or there is always uncertainty about any decisions that have been made. A condition that arises because of uncertainty with all the unfortunate consequences refers to the non-realization of business goals, namely the right costs, on time, and 


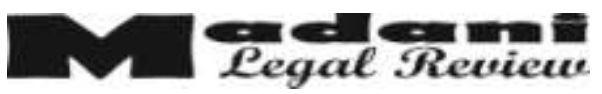

the right quality results so that the risks associated with future events and involve changes, such as, changes in mind, opinion, action, or place and involves the choice and uncertainty that the choice will be made. ${ }^{13}$

In the law, which underlies the rules relating to bank-specific risk management, which are regulated in Bank Indonesia Regulation (PBI) No. 5/8 / PBI / 2003 concerning the application of risk management for commercial banks regulating that each bank implements risk management as an effort to improve the effectiveness of banking termination, specifically:

a. Article 35 of Law 21 of 2008 concerning Sharia Banking (UUPS) (1) Islamic banks and Sharia Business Units (UUS) in carrying out their business activities must apply the precautionary principle;

b. Article 38 UUPS (1) Islamic banks and UUSs are required to apply risk management, principles to know customers, and customer protection. (2) The provisions referred to in paragraph (1) are regulated by Bank Indonesia regulations.

\footnotetext{
13 Veithzal Rivai and Rifki Ismail, Op.Cit., p.
} 63-64. c. PBI Article 2 paragraph 1 No. 9/1 / PBI / 2007 Banks are required to carry out business activities based on prudential principles and sharia principles in order to maintain or improve the soundness of banks.

\section{The Concept of Risk Management}

\section{Based on Islamic Economics}

In the early 1990s, risk awareness emerged rapidly since the onset of financial disaster. The discovery of the VAR (Value at Risk) method for measuring risk has made the growth of risk management very rapid in recent years, so a new paradigm emerges that companies basically do risk management business. ${ }^{14}$

Based on the paradigm of the Islamic economy, risk is seen as a positive thing. Business risk is associated with the concept of fairness where each result of business profits must result from involvement in dealing with business risks. Business results that are not related to the involvement in dealing with business risks are deemed not to reflect justice.

Islamic economics looks positively about risk, but Islamic economics or its derivative applications do not yet have a comprehensive risk concept. The risk concept in Islam is only about gharar and maisir. Islam forbids these two types of uncertainty. This prohibition shows that

$14 \quad$ Ibid., p. 104 
Islam has known the phenomenon of asymmetric information because this prohibition of gharar and maisir seems to be associated with the existence of asymmetric information phenomena.

Gharar is a condition of exchange by a person who has more complete information and knows more about the risk of harm with other people who do not know. Maisir is an exchange condition where all parties involved in a transaction or business cannot predict the business risk profile at all. From this, the authors conclude that Islam prohibits transactions or businesses that contain unexpected risks. ${ }^{15}$

Additional risks are things that need to be anticipated, such as risks arising from changes in the customer's business conditions after disbursing financing. There are at least three risks that can arise from changes in the customer's business conditions after disbursing financing, namely over trading, adverse trading and liquidity run.

Over trading occurs when customers develop large business volumes with the support of small capital (too much business volume with too little capital). This situation will cause a cash flow crisis.

Adverse trading occurs when a customer develops his business by taking a

$15 \quad$ Ibid., p. 107 policy of making a large fixed cost each year and playing in a market where the sales volume is unstable. Companies that have characteristics like this are companies that are potentially in a weak position and at high risk.

Liquidity run occurs when customers experience liquidity difficulties due to loss of income sources and increased expenses caused by unexpected reasons. This condition will certainly affect the ability of customers to settle their obligations to the bank. Even if you cannot predict the liquidity flow of a company, the bank can estimate whether the company has sufficient liquidity or can obtain additional funds to maintain the cash flow as usual. ${ }^{16}$

3. Optimization of the Risk Management System

\section{a. The Role of the Sharia Supervisory} Board

The Sharia Supervisory Board (DPS) has an important and strategic role in implementing Islamic principles in Islamic Banking. DPS is responsible for ensuring all Islamic bank products and procedures are in accordance with Islamic Principles. Because of the importance of the role of the DPS, the two laws in Indonesia include the necessity for such DPS in Islamic

16 Brian Coyle, Measuring Credit Risk, CIB Publishing, Kent-UK, p. 7-13, see also Adiwarman Karim, 2004, Bank Islam: Analisis Fiqih dan Keuangan, (Jakarta: PT. Raja Grafindo Persada, 2000) p. 250 


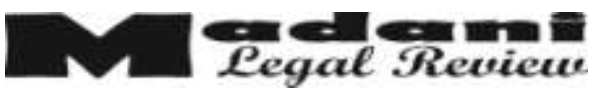

Is5n cetak 2597.9353 1 Is5n online 2580.6319

Vol. 3 No. 1 Juni 2019 companies and Islamic banking institutions, namely Law No. 40 of 2007 concerning Limited Liability Companies and Law No. 21 of 2008 concerning Sharia Banking. Thus, judicially, DPS in banking institutions occupy a strong position because their existence is very important and strategic.

The function and role of DPS in Islamic banks has a strong relevance to risk management in Islamic banking, namely reputation risk, which in turn has an impact on other risks such as liquidity risk. Islamic compliance violations that are left or escaped from the supervision of the DPS, will damage the image and credibility of Islamic banks in the eyes of the public so as to reduce public trust in the Islamic bank in question. For this reason, the role of DPS in Islamic banks must be truly optimized, the qualification to become a DPS must be tightened, and the formalization of its role must be realized in the Islamic bank. ${ }^{17}$

The Limited Liability Company Law emphasizes in its $\operatorname{article}^{18}$ in running a business based on sharia principles in addition to having the Board of Commissioners required to have a Sharia Supervisory Board (DPS). In addition, the DPS as referred to in paragraph

\footnotetext{
17 Veithzal Rivai and Rifki Ismail, Op.Cit., p. 213-215

18 Act Number 40 of 2007 concerning Liability Companies
}

consists of an or more Islamic expert appointed by the GMS on the recommendation of the Indonesian Ulema Council (MUI) and DPS as referred to in paragraph (1) whose task is to provide advice and advice to the Directors and oversee the activities of the company to conform to Islamic principles.

Likewise in the Islamic banking law, ${ }^{19}$ it explains in the article that DPS must be established in Islamic Banks and conventional Commercial Banks that have UUS. As referred to in paragraph (1), the general meeting of shareholders is fixed at the recommendation of the MUI. DPS is tasked with providing advice and advice to directors and overseeing bank activities to conform to Islamic principles.

\section{b. Implementation of the Prudential Principle in Minimizing Risks}

Article 2 of the Banking Act (UUP) Jo the Sharia Banking Act (UUPS) confirms that Indonesian banks carry out their business based on economic democracy using the principle of prudence. The article applies to every bank that carries out its business activities in Indonesia, both commercial banks and community credit banks, because this is related to the function of banks as intermediary institutions. It can be concluded that Islamic banks as intermediary institutions

\footnotetext{
19 Act Number 21 of 2008 concerning Sharia Banking
} 


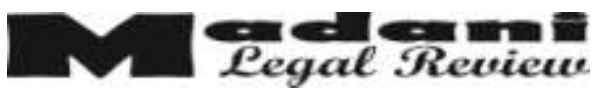

must always apply the principle of prudence, even though Islamic banks use sharia principles based on Islamic law in carrying out their business.

In a sharia financing the application of the precautionary principle is absolute, because the risks borne by Islamic banks outweigh the risks borne by conventional banks in providing credit, although this is related to the $100 \%$ borne by the bank and the existence of guarantees in Islamic finance. In each provision of Islamic finance, Islamic banks must pay attention to matters as specified in Article 8 paragraph (1) and (2) UUP Jo. Article 35 UUPS which states that, in providing credit or financing based on sharia principles, commercial banks must have confidence based on in-depth analysis or good faith and the ability and ability of debtor customers to pay off their debts or return the intended financing in accordance with the agreement. Similarly, commercial banks are required to have and implement guidelines for credit and financing based on sharia principles, in accordance with the provisions stipulated by Bank Indonesia.

According to the Elucidation of Article 8 paragraph (2) of UUP Juncto Article 35 of the UUPS it is stated that the guidelines for credit and financing are based on the principle of sharia stipulated by Bank Indonesia which must be owned and applied by banks in providing credit and Islamic finance. The provisions of Article 8 paragraph (1) and (2) UUP Juncto Article 35 of the UUPS, constitute the basis or foundation for Islamic banks in channeling Islamic finance to customers. Moreover, because channeling funds to the community is one of the main functions of the bank, the provision indirectly constitutes a continuation of Article 2 of UUP and UUPS, which requires banks to apply the principle of prudence in carrying out their business. To prevent the occurrence of troubled financing in the future, the valuation of an Islamic bank to give approval for a sharia financing application is carried out by referring to the 5C Principle. These principles are character, capacity, capital, collateral, and condition of economic. ${ }^{20}$

Basically, relating to the distribution of Islamic finance from Islamic banks to customers is guided by two things, namely trust and prudence. Trust in this case means that Islamic banks have the belief that the channeled Islamic finance is useful and running well, so that it can benefit all parties in Islamic finance. The most important thing in trust is that Islamic banks believe that the customer concerned is able to carry out their business well so

20 Hermansyah, Hukum Perbankan Nasional Indonesia, (Jakarta: Pemuda Media, 2005), p. 125 
that the customer can return the principal and the business can provide benefits for shâhib al-mâl (third party fund holders), Islamic banks, and mudharib. Regarding prudence in this case can be realized in the form of consistent application based on good faith in all requirements and legislation related to the distribution of Islamic finance by Islamic banks. In addition to conducting financing analysis, another thing that must be done by banks in applying the precautionary principle in Islamic finance is to set a maximum credit limit. This is needed to establish the financing ceiling to be provided by Islamic banks to customers. Islamic banks are prohibited from providing a number of funds which if they cannot be utilized and returned by the customer. The application of the precautionary principle is not only prioritized to be applied by Islamic banks in its financing products, but broadly the precautionary principle must also be applied by Islamic banks to products that are deposits. In receiving funds from the public, Islamic banks are required to obtain information as clearly as possible, whether it is information about creditors' customers from Islamic banks, as well as sources of funds owned by customers of these creditors. This was done to prevent the occurrence of money laundering crimes.

\section{c. Optimization of the Role of Internal} Audit

In maximizing risk management, the internal audit role is also needed. However, in the Islamic banking system, Islamic audits with a Balance Scorecard framework are needed to deal with this.

Islamic audit is a comprehensive testing of sharia compliance with the activities of Islamic banks. The main objective of sharia auditing is to ensure the suitability of all bank operations with sharia principles and rules which are used as guidelines for management in operating Islamic banks so that Islamic audits are expected to ensure that all activities and products of Islamic banks are in accordance with Islamic rules and principles. But in practice sharia audits are often carried out only limited to testing the suitability of Islamic bank products with existing Islamic principles and rules, while the operational aspects of other banks are neglected. As a result, the main objective of the implementation of Islamic sharia audits was not achieved so that the stakeholder needs of Islamic banks to guarantee sharia compliance became minimal. This happens because there is no framework that has become a complex and comprehensive reference for implementing sharia audits. 


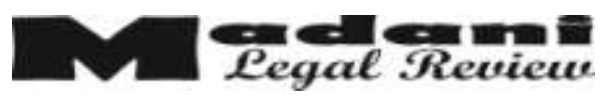

Balance scorecard as one of the contemporary management tools to assess management performance in a complex and comprehensive manner can be used as an alternative to the framework for implementing sharia audits in Islamic banks. Islamic sharia auditing with a balanced scorecard framework will be an overall assessment of Islamic sharia compliance not only in the aspect of financial products, but also in nonfinancial aspects. Balance scorecard as a framework for implementing Islamic sharia audits in Islamic banks will make the implementation of sharia audits comprehensive and will be able to provide a comprehensive picture of management's compliance with sharia principles and rules. $^{21}$

\section{CLOSING}

The concept of management Business risk in Islamic economics is associated with the concept of justice where every outcome of business profits must be generated from involvement in dealing with business risks. Business results that are not related to the involvement in dealing with business risks are deemed not to reflect justice.

Optimizing Islamic banking risk management can be concluded in several ways including 1) The Role of the Sharia

\footnotetext{
21 Veithzal Rivai and Rifki Ismail, Op.Cit., p.
} 545-546.
Supervisory

Board

(DPS)

Implementation of the Prudential Principle and 3) Internal audit optimization.

\section{BIBLIOGRAPHY}

Best, Philip, Implementing Value at Risk, John Wiley \& Sons Ltd., West Sussex, 1998.

Cade, Eddie, Managing Banking Risk, American Management Association, New York,1999.

Coyle, Brian, Measuring Credit Risk, CIB Publishing, Kent-UK, 2000.

Djojosoedarsono, Soeisno, Prinsip-Prinsip Manajemen Risiko dan Asuransi, Salemba Empat, Jakarta, 1999.

Hennie Van Greuning and Zamir Iqbal, Risk Analysis for Islamic Banks, World Bank, Washington DC, 2008 Hermansyah, Hukum Perbankan Nasional Indonesia, Pemuda Media, Jakarta, 2005

Karim, Adiwarman, Bank Islam: Analisis Fiqih dan Keuangan, PT. Raja Grafindo Persada, Jakarta, 2004.

Khan, Tariqullah, and Habib Ahmed, Risk Management: An Analysis of Issues in Islamic Financial Industry, Occasional Paper, IDB and IRTI, Jeddah, 2001

Rivai, Veithzal, and Rifki Ismail, Islamic Risk Management for Islamic Banking, Gramedia, Jakarta, 2013.

Santoso, Wimboh and Enrico Heriantoro, "Market Risk di PerbankanIndonesia", 
Kajian Stabilitas Keuangan, No. 1

June, Jakarta, Bank Indonesia, 2003.

Soekanto, Soejono, Pengenalan Penelitian

Hukum, Grafindo, Jakarta, 2006.

Tampubolon, Robert, Risk Management,

Qualitative Approach Aplied to

Commercial Bank, PT. Elex Media

Komputindo, Jakarta, 2004.

Act Number 21 of 2008 concerning

Sharia Banking

Act Number 40 of 2007 concerning

Liability Companies 